Kon, S. K. \& Thompson, S. Y. (1949b). Arch. Biochem. $24,233$.

Krause, R. F. \& Pierce, H. B. (1948). Arch. Biochem. 19, 145.

Lovern, J. A., Mead, T. H. \& Morton, R. A. (1939). Biochem. F. 33, 338.

Lovern, J. A. \& Morton, R. A. (1939). Biochem. F. 33, 330.

Lovern, J. A., Morton, R. A. \& Ireland, J. (1939). Biochem. F. 33, 325.

McCoord, A. B. \& Clausen, S. W. (1948). Abstr. Pap. Amer. Chem. Soc. I14th Mtg, p. I6c.

Mattson, F. H. (1948). J. biol. Chem. 176, 1467.

Mattson, F. H., Mehl, J. W. \& Deuel, H. J. Jr. (1947). Arch. Biochem. 15, 65.

Meunier, P., Jouanneteau, J. \& Zwingelstein, G. (1950). C.R. Acad. Sci., Paris, 231, I 170.

Moore, T. (1930). Biochem. F. 24, 692.

Moore, T. (1931). Biochem. J. 25, 275.

Popják, G. \& Beeckmans, M. L. (1950). Biochem. F. 47, 233.

Popper, H. \& Greenberg, R. (1941). Arch. Path. 32, 11.

Popper, H. \& Volk, B. W. (1944). Arch. Path. 38. 71 .

Sexton, E. L., Mehl, J. W. \& Deuel, H. J. Jr. (1946). F. Nutrit. 31, 299.

Stallcup, O. T. \& Herman, H. A. (1950). F. Dairy Sci. 33, 237.

Swick, R. W., Grummer, R. H. \& Baumann, C. A. (r 949). F. Anim. Sci. 8, 645.

Thompson, S. Y., Braude, R., Coates, M. E., Cowie, A. T., Ganguly, J. \& Kon, S. K. (1950). Brit. F. Nutrit. 4, 398.

Thompson, S. Y., Braude, R., Cowie, A. T., Ganguly, J. \& Kon, S. K. (1949). Biochem. F. 44, ix.

'Thompson, S. Y., Coates, M. E. \& Kon, S. K. (1950). Biochem. Y. 46, xox.

Thompson, S. Y., Ganguly, J. \& Kon, S. K. (1947). Brit. F. Nutrit. I, v.

Thompson, S. Y., Ganguly, J. \& Kon, S. K. (1949). Brit. F. Nutrit. 3, 50.

Verzár, F. \& McDougall, E. J. (1936). Absorption from the Intestine, p. 222. London: Longmans, Green and $\mathrm{Co}$.

Wagner, K. H.(1939). Vitamin A und B-Carotin des Fin-, Blau-und Spermwals. Leipzig:Johann Ambrosius Barth.

Wiese, C. E., Mehl, J. W. \& Deuel, H. J. Jr. (1947). Arch. Biochem. 15, 75.

\title{
Vitamin A Levels in Health and Disease
}

\section{By T. Moore and I. M. Sharman, Dunn Nutritional Laboratory, University of Cambridge and Medical Research Council}

The antimony-trichloride method for estimating vitamin A has now been available for nearly 25 years, and has been used to study the metabolism of the vitamin in man and animals by numerous workers all over the world. It is not surprising, therefore, that the wealth of literature is quite beyond compression into a short review, so that we cannot hope to outline more than a few of the main developments in the field, with emphasis on points in which we have been personally interested.

The levels of vitamin $A$ in the blood plasma and tissues are influenced by numerous factors, including the rate of intake of vitamin A or carotene, the efficiency of absorption from the intestines, the storage of vitamin $\mathrm{A}$ in the liver and other tissues, its mobilization from the liver into the blood plasma, and its removal from the plasma by transfer to the tissues, by destruction, and sometimes by urinary excretion. The various stages in the absorption, mobilization and utilization of the vitamin, however, probably overlap considerably. Thus, it must not be concluded that the vitamin invariably passes through the liver before being transferred to other tissues.

\section{Absorption}

Preformed vitamin A is generally much more efficiently absorbed than carotene, although the disparity decreases, and possibly eventually disappears, at low levels of dosing. Numerous investigations have been made on the effect of massive doses of 
vitamin $A$ in raising its level in the blood plasma. In normal subjects a sharp rise, mainly in esterified forms of the vitamin, is observed 4-5 hr. after dosing, followed by a return to the resting value within $24 \mathrm{hr}$. 'Absorption' or 'tolerance' curves may be readily obtained, and have been used in America as a measure of the efficiency of fat absorption. Flattened curves are observed in diseases such as sprue, coeliac disease and infective hepatitis, in which the absorption of fat is affected. On the other hand, greatly elevated curves have been observed in nephrosis. Thus, Kagan, Thomas, Jordon \& Abt (1950) found that children suffering from this disease not only had a very high resting level of vitamin $A$, but showed a much greater increase after dosing. In general the high levels of fat in the plasma, which are characteristic of nephrosis, tended to be associated with high concentrations of vitamin A, but the correlation was not close. The authors concluded that in nephrosis the power of the liver to absorb or utilize vitamin $\mathrm{A}$ is seriously impaired.

Numerous investigations have clearly demonstrated that in conditions with impaired fat absorption vitamin $A$ is absorbed much more efficiently from aqueous emulsions made with the Tween group of non-ionic detergents than from oily solutions. Medicinal paraffin, although having little effect on the absorption of preformed vitamin A by normal subjects, is well known to interfere considerably with the absorption of carotene.

\section{Storage and distribution}

Experiments on rats and other animals have established that the body's main stores of vitamin A are usually located in the liver, being concentrated in both the liver cells and Kupffer cells. Recently experiments by Johnson \& Baumann $(1947 a, b)$, however, have indicated that, in rats given doses of about 30 i.u. vitamin $A$ or carotene daily, the amounts of vitamin A present in the kidneys exceed those in the liver. Eden \& Moore (1950) have confirmed this surprising observation, and have drawn attention to the failure of the concentration of vitamin $A$ in the kidneys to increase parallel with that in the liver when large doses of vitamin A were given. With liberal intakes of vitamin A substantial amounts appear in the lungs, adrenal glands and fat deposits.

Although more is known about the metabolism of vitamin $\mathrm{A}$ in the eye than in any other organ, it is important to realize that the retina normally contains only a very minute fraction of the total amount present in the body.

In studies of the distribution of vitamin A in the cells, fluorescence microscopy has given interesting results in the hands of Popper \& Greenberg (r94r) and others. In macroscopic examinations of the adipose tissue of rats we have observed yellow fluorescence under ultraviolet irradiation in animals given massive doses of vitamin A, but not in animals given inadequate doses. We have sometimes been able, however, to detect vitamin A by the antimony-trichloride reaction in specimens of fat which showed no yellow fluorescence. With some fluorescent tissues, moreover, the fluorescence was absent from the fat as extracted with ether, and remained associated with the residual tissues. In preliminary tests we succeeded in extracting the fluorescent substance from the residue with hot $50 \%$ ethyl alcohol; from its distribution between ether and water it appeared to be water soluble. 
Quantitative aspects. Since the early experiments by Moore (1930), it has been recognized that much larger doses of carotene or vitamin $A$ are needed to cause storage of vitamin $\mathrm{A}$ in the livers of rats than to promote normal growth. Lemley, Brown, Bird \& Emmett (1947) found that over the range of dosage which they investigated the percentage of vitamin stored increased with the magnitude of the dose up to an optimum point, after which there was a decline when very heavy doses were given.

Davies \& Moore (1948) obtained similar results. In rats depleted of vitamin A single doses of roo i.u. caused no storage in the liver. Larger doses were stored with increasing efficiency, until with 50,000 i.u. the efficiency of storage reached $85 \%$. With prolonged heavy dosing, however, the efficiency of storage decreased, presumably on account of saturation of the liver. At such levels the rats are in danger of hypervitaminosis $\mathrm{A}$, characterized by broken bones, mainly in young animals, and sudden severe haemorrhage (see Moore \& Wang, 1945).

'The observation that low doses of vitamin A cause no storage in the liver lends colour to the report by Le Gallic (1947) that under certain circumstances the blood and tissues of albino rats may possess biological activity without containing significant amounts of vitamin A or carotene, as measured chemically. This conclusion, if confirmed, would suggest that vitamin A may exert its activity indirectly through transition into another substance, which might explain why the vitamin profoundly affects tissues, such as the mucous membranes and bones, in which its presence cannot be detected by chemical methods. In spite of numerous attempts, however, we have so far failed to confirm Le Gallic's observations.

Storage in different animals. The vitamin A reserves in different animals have been extensively investigated. The short list of values given in Table I may serve to demonstrate the extremely wide variations which are found between species. For each animal

Table I. Storage of vitamin $A$ in the livers of various animals

\begin{tabular}{lcc}
\multicolumn{1}{c}{$\begin{array}{c}\text { Vitamin A content } \\
\text { (i.u./g. liver) }\end{array}$} \\
Guinea-pig & 10 & Normal human range \\
Pig & 100 & (median 320) \\
Cow & 150 & \\
Rabbit & 170 & \\
Rat, wild & 250 & \\
Sheep & 600 & \\
Cod fish & 2,000 & \\
Sperm whale & 4,400 & Toxic \\
Bearded seal & 13,000 & Range for \\
Polar bear & 20,000 & experimental rat
\end{tabular}

the individual values also usually vary considerably, and most of the values given are means for groups. Since, moreover, the reserves are greatly influenced by the composition of the diet, they can be considered as typical only when the animal is adhering to its usual feeding habits. Thus, though a reserve in the liver of $250 \mathrm{i} . \mathrm{u} . / \mathrm{g}$. might be considered as typical for wild rats in this country, values of from o to $20,000 \mathrm{i} . \mathrm{u}$./g. may readily be obtained by suitable adjustment of the diets of rats kept in the laboratory. 
For man the range in this country, as found for cases of accidental death, extends from ro to about 2000 i.u./g. Moore (1949) found a median of about 320 i.u./g.

In spite of the influence of diet there are two clear instances in which animals on much the same diet have widely different reserves. Thus sheep at pasture have liver reserves of 600 i.u.jg., compared with only 150 i.u. for cattle under the same conditions. Guinea-pigs, according to our estimations on animals kindly provided by Miss H. M. Bruce, have very much lower reserves than rabbits. Thus guinea-pigs, given a diet of cubes and greens, had only 1o i.u./g. compared with 170 i.u./g. for rabbits on the same regime. Since, in our experience, the livers of guinea-pigs can accumulate large reserves if large doses of the preformed vitamin are given, it would appear that the frequent occurrence of low reserves in this animal, which was first reported by Chevallier \& Choron (1935), may be due to inefficiency in the conversion of carotene.

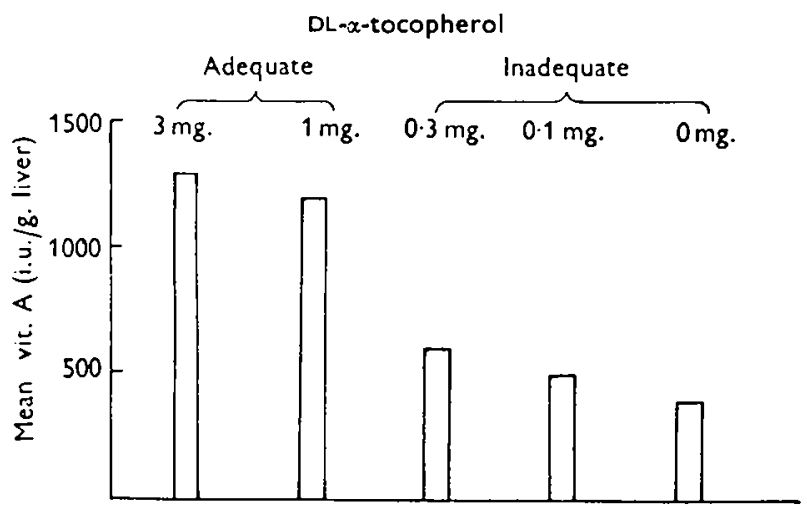

Fig. I. Storage of vitamin $A$ in the liver by female rats given rooo i.u. vitamin $A$ weekly for about 6 months, in conjunction with doses ranging from o to $3 \mathrm{mg}$. DL- $x$-tocopherol weekly.

The early experiments of Dann (1932) established that in rats vitamin A is transferred in limited amounts from the mother to the foetus, and the reserves in newborn animals have generally been found to be much lower than in adults. Thus the livers of calves at birth usually contain per g. about ro i.u., those of lambs 30 i.u., and of human babies 20 i.u. A substantial contribution of vitamin $A$ is provided by the colostrum.

$V i t a m i n E$ and the storage of vitamin $A$ in the rat. The effect of vitamin $E$ deficiency on vitamin A reserves was first reported by Moore, Martin \& Rajagopal (1939). Fig. I is based on observations by Moore (1940) in which pairs of female rats were kept for about 6 months on a basal diet with supplements of rooo i.u. vitamin $A$ and of from o to $3 \mathrm{mg}$. DL- $\alpha$-tocopherol, weekly. With doses of $\mathrm{I}$ and $3 \mathrm{mg}$. of tocopherol, which were adequate judged by the colour of the uterus at autopsy, much higher stores of vitamin $\mathrm{A}$ were accumulated in the liver than with inadequate doses of from $\circ$ to $0.3 \mathrm{mg}$.

Sex and the storage and distribution of ritamin A. Booth (Medical Research Council, 1949) and others have noticed that the vitamin $A$ reserves in the livers of female rats are consistently higher than in those of males receiving the same diets. In recent experiments we have confirmed this conclusion at various levels of dosing. Fig. 2 shows the total amounts of vitamin $A$ found in the livers and kidneys of male and female rats, expressed as percentages of the total amount ingested during the $4-5$ weeks during 
which the rats received the basal diet. It will be noticed that at all levels of dosing, except that of ro i.u. daily, the reserves of the females exceeded those of the males. In confirmation of previous conclusions, moreover, the efficiency of storage tended in both sexes to rise with the magnitude of the doses given (see p. 121).

The effect of sex was perhaps more strikingly seen in the different distribution of the vitamin between the kidneys and liver. The average concentration in these organs at various levels of dosing has already been reported (Moore \& Sharman, 1950) and

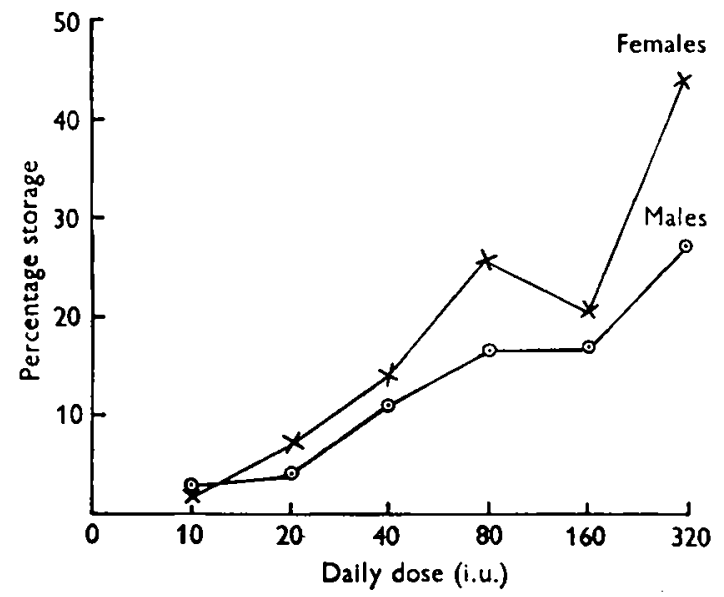

Fig. 2. Amount of vitamin A stored in the livers and kidneys of male and female rats, expressed as a percentage of the amount ingested.

showed that, contrary to observations on the liver, the kidneys of males consistently contained more vitamin A than those of females. Fig. 3 shows individual values for male and female animals that had received doses of 40 i.u. vitamin $A$ daily for about 4 weeks. At this critical level of dosing the concentration of vitamin A in the kidneys of males was invariably greater than in their livers, whereas in the females the situation was reversed, the concentration in the liver being invariably much greater than in the kidneys.

Johnson \& Baumann (1947b) have observed that vitamin A was transferred from the liver to the kidneys during rapid growth. It therefore remains to be decided to what extent the greater concentration of vitamin $A$ in the kidneys of male rats can be explained by their growing more rapidly than females. Two preliminary experiments on the effect of sex hormones on the distribution of vitamin A may, therefore, be of interest.

In one experiment male rats, which possessed substantial initial reserves of vitamin A in their livers, were either left entire or were castrated through the kind co-operation of Dr E. Kodicek. Some of the castrated animals received testosterone by injection, others oestradiol, while the rest had no injections. All the animals were kept on a basal diet with 80 i.u. vitamin A daily for about ro days, and were then killed. The mean concentration of vitamin A in the kidneys was 4.3 i.u./g. in the entire rats, 5.3 in the castrated animals treated with testosterone, 2.9 in those castrated and treated with oestradiol, 
and 3.0 in the castrated animals given no injections. Throughout these experiments the kidneys were unusually low in vitamin $A$ for male animals. The results suggest, however, that castration tended to lower the concentration of vitamin $A$ in the kidneys, and that its effects might be neutralized by testosterone but not by oestradiol.
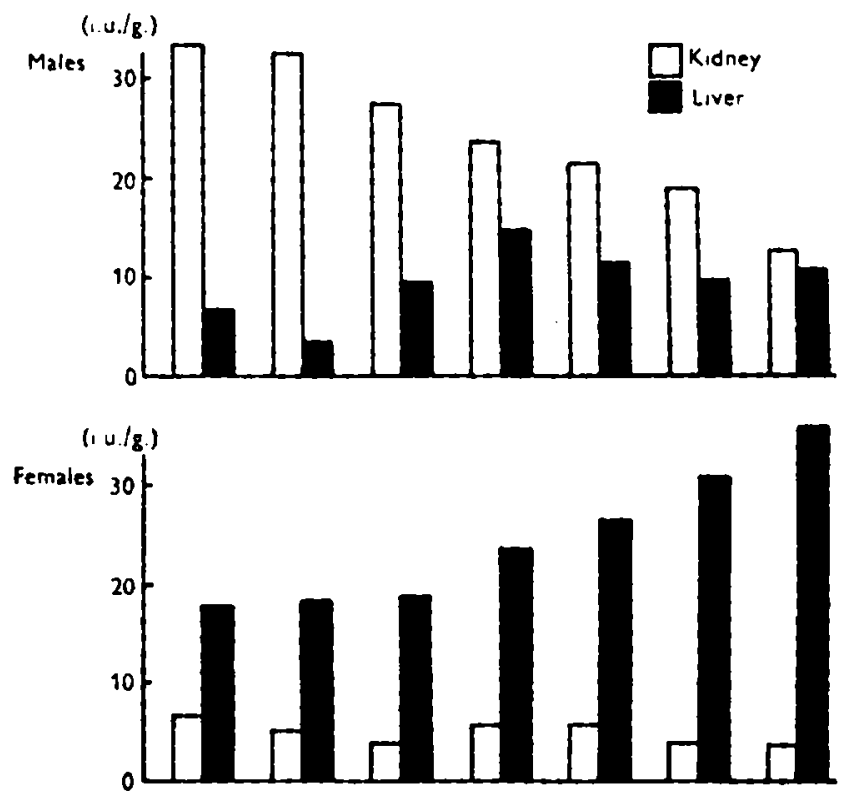

Fig. 3. Concentration of vitamin $A$ in the liver and kidneys of individual male and female rats given to i.u. vitamin A daily.

In another experiment depleted female rats were given $40 \mathrm{i} . \mathrm{u}$. vitamin A daily for several weeks in conjunction with a basal diet containing $0.1 \%$ of stilboestrol. The subcutaneous adipose tissues had a bright golden fluorescence. Extraction with ether gave fat with a vitamin A content of 5 i.u./g. The fluorescence, however, remained with the residue of the tissues, from which it could be extracted with hot $50 \%$ ethanol. The adipose tissues of rats not given stilboestrol showed no yellow fluorescence.

\section{Vitamin $A$ reserves in human diseases}

Table 2 presents a rearrangement of data collected by Moore (1937) on the median vitamin $A$ reserves found in groups of human subjects who died by accident within 7 days of injury or from various diseases. It will be seen that reserves above the level of those dying from accidents, of $220 \mathrm{i} . \mathrm{u} . / \mathrm{g}$. liver, were found in diabetes and also in thyroid diseases. In poisoning and hernia the reserves were only slightly below the level for accident cases, but with all other causes of death they were considerably less. It appears, therefore, that in most fatal diseases at least half the vitamin A reserves disappear, although it is uncertain whether the loss is due mainly to increased destruction or is partly due to defective absorption or to a reduced intake of food.

Further examination of the data indicates that the reserves are more severely reduced in some diseases than in others. Thus infections of the head and spine gave a median 
Table 2. Median vitamin $A$ reserves in the livers of human subjects, aged I 5-59 years, who died from accident or from various diseases (rearranged from Moore, 1937)

\begin{tabular}{|c|c|c|c|c|c|}
\hline Cause of death & $\begin{array}{l}\text { No of } \\
\text { cases }\end{array}$ & $\begin{array}{c}\text { Vitamin } \\
\text { A } \\
\text { reserves } \\
\text { (i.u./g. } \\
\text { liver) }\end{array}$ & Cause of death & $\begin{array}{c}\text { No. of } \\
\text { cases }\end{array}$ & $\begin{array}{c}\text { Vitamin } \\
\text { A } \\
\text { reserves } \\
\text { (i.u./g. } \\
\text { liver) }\end{array}$ \\
\hline Thyroid diseases & 9 & 310 & Septic endocarditis & 33 & 90 \\
\hline Diabetes & 15 & 300 & Thrombosis, embolism & 23 & 89 \\
\hline Accident & 40 & 2200 & Bronchiectasis & 12 & 82 \\
\hline Poisoning & 13 & 170 & Subacute nephritis & 12 & 75 \\
\hline Hernia and some other conditions & 10 & 160 & Peritonitis & 12 & 75 \\
\hline Blood diseases & 31 & 130 & Enteritis, colitis & II & 74. \\
\hline Cerebral haemorrhage & 26 & 120 & Head, spine infections & 52 & 73 \\
\hline Gastric and duodenal ulceration & 43 & 110 & Pneumonia & 22 & 63 \\
\hline Appendicitis & 19 & I 10 & Empyema & 12 & 60 \\
\hline Gall-bladder diseases & 13 & I Io & Valvular heart disease & 56 & 60 \\
\hline Cancer & 76 & I 10 & Abscesses & 35 & 51 \\
\hline Nerve degenerations & 13 & Iro & Prostate diseases & $23 *$ & 40 \\
\hline Coronary disease & 20 & 100 & Chronic nephritis & 48 & 25 \\
\hline Tuberculosis & 26 & 96 & Urinary infections & 13 & 19 \\
\hline Syphilitic aortitis & 27 & 95 & & & \\
\hline & & - All a & & & \\
\hline
\end{tabular}

value of 73 i.u./g. liver and abscesses in other sites one of $5 \mathrm{r}$. For pneumonia the median value was 63 , and for empyema 60 . The lowest values of all were found for urinary diseases, with 25 for chronic nephritis, and 19 for urinary infections. It may be significant that some of the diseases in which low vitamin A reserves were found, including pneumonia, abscesses and urinary infections, are among the more common terminations to vitamin A deficiency in experimental animals. Particular attention may perhaps be directed to the several independent links which now appear to connect urinary diseases with vitamin A deficiency or abnormalities in vitamin A metabolism. Thus it has long been known that vitamin A deficiency in rats frequently leads to fatal urinary infections, often with the production of calculi. In our experience these infections are by far the most common termination to prolonged or repeated vitamin $A$ deficiency. From the more recent investigations described on p. 120 we have learnt that when only small amounts of vitamin $A$ are available the kidney has priority, even over the liver, in absorbing them. In chronic nephritis and urinary infections the vitamin A reserves are usually low, and often completely exhausted. Chronic nephritis is prominent among those diseases in which vitamin $\mathrm{A}$ is lost by urinary excretion, and in nephrosis the failure of the liver to absorb vitamin $A$ from the blood plasma has been strongly indicated. Much further research will, however, obviously be necessary before it can be decided how far vitamin A deficiency, either dietary or conditioned in origin, affects the progress of human kidney diseases.

\section{Vitamin $A$ in human blood}

Investigations of the levels of vitamin $\mathrm{A}$ and of carotenoids in the plasma of inhabitants of this country have been made recently by Moore \& Leitner (1949) and by Campbell \& Tonks (1949). These results, together with those of the American workers 
Kimble (1939), Abels, Gorham, Pack \& Rhoads (1941) and Murrill, Horton, Leiberman \& Newburgh (1941) are given in Table 3. Some uncertainty in the comparison of the British and American results for vitamin A must arise from unintentional differences in

\section{'Table 3. Values for vitamin $A$ and carotenoids in human blood plasma}

\begin{tabular}{llccc}
\multicolumn{1}{c}{ Authority } & Country & $\begin{array}{c}\text { No of } \\
\text { subjects }\end{array}$ & $\begin{array}{c}\text { Carotenoids } \\
\text { (i.u./100 ml.) }\end{array}$ & $\begin{array}{c}\text { Vitamin A } \\
\text { (i.u./100 ml.) }\end{array}$ \\
Moure \& Leitner (1949) & Great Britain & 195 & 150 & 120 \\
Campbell \& Tonks (1949) & Great Britain & 110 & 133 & 108 \\
Kimble (1939) & United States & 64 & 294 & 109 \\
Abels et al. (194) & United States & 124 & 325 & 160 \\
Murrill et al. (1941) & Linited States & 45 & 343 & 104
\end{tabular}

the magnitude of the units (cf. Hume, I951), but the round figure of 120 i.u./100 ml. quoted by Moore \& Leitner is not far removed from the American values. The values for carotenoids, however, appear to be much greater in America than in Britain, probably on account of dietary differences.

As a point of interest it may be mentioned that in collaboration with $\mathrm{Dr} \mathrm{H}$. C. Trowell of the Uganda Medical Service we have found that carotenoids are often virtually absent from the plasma of native infants suffering from kwashiorkor. Individual values found were $6,10,11$ and 25 i.u./ $/ 100 \mathrm{ml}$, and ranged from about 2 to $8 \%$ of the values found for healthy, well-nourished Americans. It remains to be decided whether this virtual absence of carotenoids from the plasma is dietary in origin or is a secondary effect of the disease.

Physiological factors affecting the level of vitamin $A$ in the plasma. Our knowledge of the factors which control the mobilization of vitamin $A$ from the liver into the blood plasma is still very limited. According to Clausen and his co-workers, the administration of alcohol to dogs or human beings causes a rise in the vitamin A level of the plasma (Clausen, Baum, McCoord, Rydcen \& Breese, 1940; Clausen, Breese, Baum, McCoord \& Rydeen, 194I). In the Sheffield experiment, however, heavy doses of alcohol had no effect on the vitamin $A$ level of two of the volunteers who were tested (Hume \& Krebs, 1949).

Sex is obviously an important factor in influencing the plasma level. In examinations of human plasma both Kimble (1939) and Moore \& Leitner (1949) observed slightly higher mean values for males than for females. In recent experiments with rats we have observed differences in the same direction between groups of males and females given various doses of vitamin A. Using immature pullets, Chapman, Gluck, Common \& Maw (1949) have obtained spectacular results with combined injections of oestradiol and testosterone, the vitamin A content of the plasma being about doubled. According to Bodansky, Lewis \& Lillienfeld (1943), pregnancy has a slight effect on the plasma level of vitamin $\mathrm{A}$ in human subjects, causing decreased values in the later stages.

Effect of disease on the level of vitamin $A$ in the plasma. The level of vitamin A in the plasma may be influenced by disease in various ways. The effect of diseases characterized by the defective absorption of fat has already been mentioned (p. 120). Disease may interfere also with the mechanisms controlling the transfer of the vitamin between the 
liver, plasma and other tissues, or may increase the rate of expenditure of the vitamin above the physiological level.

The effects of fever were extensively investigated by Lindqvist (1938), who found greatly reduced levels of vitamin A in the plasma in pneumonia, influenza, tuberculosis and other infections. The levels returned to the normal range promptly on recovery. Many other workers have amply confirmed these observations. It is interesting that Moore (1937) found low liver reserves in fatal cases of pneumonia, suggesting that the decline in the plasma level in this disease indicates not only a failure in mobilization, but the actual loss of a large fraction of the vitamin A reserves of the body.

Shank, Coburn, Moore \& Hoagland (1944) have investigated the relationship between vitamin $A$ and rheumatic fever. The low reserves frequently observed by Moore (1937) and Ellison \& Moore (1937) in vascular heart diseases suggested that prolonged attacks of this disease might adversely affect the vitamin A status. With $\mathrm{Dr}$ Leitner we have made numerous serial estimations of vitamin $A$ in the plasma of patients suffering or recovering from acute rheumatism. In general, the average level of vitamin $A$ rose towards the normal average during the first few weeks of recovery, the return to normal matching the decline in the body temperature and erythrocyte sedimentation-rate. The carotenoid levels, however, remained much below the normal average.

Clear evidence that a very low level of vitamin $A$ in the plasma does not necessarily imply exhaustion of the liver reserves was obtained by Harris \& Moore (1947) in a fatal case of infective hepatitis. A specimen of plasma collected a few days before death contained only I9 i.u./100 ml., whereas the liver contained no less than $900 \mathrm{i} . u . / g$., or about three times the average level.

With Dr Leitner we have noticed that the level of vitamin A in the plasma is often very low in patients with fatal illness, even when pyrexia is absent. Thus, estimations on eight patients made within $\mathrm{I}_{4}$ days of death gave a mean value of only $3^{8} \mathrm{i} . \mathrm{u} . / 100 \mathrm{ml}$. The conclusion that fever is not the only factor influencing the ability of the plasma to maintain a normal concentration of vitamin $A$ is supported by the frequent occurrence of very low values in certain skin diseases, which is discussed more fully by Dr Leitner (Leitner, 195 I).

\section{Urinary excretion of vitamin $A$}

Since vitamin A is soluble only in fat, its presence would not be expected in urine. This conclusion is fully borne out for normal human urine, which is completely free from the vitamin even when large doses are ingested. Boller \& Brunner (1936) and Boller, Brunner \& Brodaty (1937), however, made the surprising discovery that patients with certain diseases, including pneumonia, chronic nephritis, and icterus with closure of the biliary duct, passed considerable amounts of vitamin A into their urine. Catel $(1938 a, b)$ made the no less unexpected observation that large amounts of vitamin A are usually present in dog's urine.

The presence of vitamin $A$ in the urine in pneumonia was confirmed, the amount lost reaching 3000 i.u. daily in one patient (Lawrie, McArdle \& Moore, 1938; Lawrie, Moore \& Rajagopal, 1941). Smaller amounts were excreted in chronic nephritis. The urine of apparently healthy dogs contained the vitamin, but none was excreted by rats, 
even when diseased, or by rabbits. Vitamin $\mathrm{A}$ in human urine was not accompanied by carotenoids, as in the plasma. Patients excreting the vitamin always had some degree of proteinuria, but heavy excretion of protein was sometimes observed without any excretion of the vitamin.

\section{Some outstanding problems}

The numerous investigations that have been reviewed admittedly represent only a small fraction of the material which is available. They indicate clearly, however, that the vitamin $A$ levels in the body may be influenced by many factors other than the dietary intake, and that lesions which could be caused by vitamin $A$ deficiency are a commonplace in many diseases in which the sufferers are receiving ordinary diets.

In further research more information should be sought on the factors controlling the mobilization and distribution of the vitamin. Can secondary deficiency result through failure in the mobilization mechanism even when vitamin $\mathrm{A}$ is present in the liver? If so, are there any means available to rectify faulty mobilization? Another problem is presented by the disappearance from the body of large amounts of the vitamin, under either normal or pathological conditions. What are the degradation products? In the behaviour of retinene and of vitamin $A$ acid we have hints that the oxidation products of the vitamin may have biological importance, but we remain ignorant as to its ultimate metabolic fate.

Vitamin $A$ and metabolic stress. Hardly less important is the question of whether any benefit, beyond provision for the future, is derived from an intake of vitamin A substantially above the minimum level, such as allows the accumulation of a substantial liver reserve. Have the large amounts of vitamin A which we know to be present in the livers of most of the inhabitants of this country any functional purpose?

An important step towards answering this question has recently been made by Meunier, Ferrando, Jouanneteau \& 'Thomas (1949). When rats were given a diet, deficient in vitamin $\mathrm{A}$ and containing $2 \%$ of sodium benzoate, they declined and died, even when given a dose of $2.5 \mu \mathrm{g}$. vitamin A, which would amply have supplied their requirements in the absence of sodium benzoate. Good growth and survival for an indefinite period were, however, secured even in the presence of benzoate by increasing the vitamin A allowance to $20 \mu \mathrm{g}$. daily. A substance which was toxic at the lower level of dosing with vitamin A thus became innocuous at the higher level. Further experiments, made later with bromobenzene, gave similar results (Meunier, Ferrando \& Perrot-Thomas, 1950).

In investigations along similar lines we have examined the effect of the vitamin A allowance on the resistance of rats to stilboestrol poisoning. Both vitamin A deficiency and stilboestrol cause cornified vaginal smears in rats, and it seemed of interest to oppose the vitamin with its curative action on deficient animals to an agent which would not allow the vaginal surface to function normally. With doses of 4 i.u. vitamin A daily, the presence of stilboestrol in the diet reduced the mean weight increase in 4 weeks to $6 \mathrm{~g}$. from $23 \mathrm{~g}$., whereas with a daily dose of 40 i.u. the weight increase was reduced only to $25 \mathrm{~g}$. from $34 \mathrm{~g}$. 
In other experiments we have obtained indications that the adverse effect of an unheated room on the growth of rats may sometimes be partially corrected by increasing the vitamin $\mathrm{A}$ allowance. The conditions necessary to demonstrate this possible beneficial action of the vitamin were, however, achieved in two only out of four experiments.

\section{REFERENCES}

Abels, J. C., Gorham, A. T., Pack, G. T. \& Rhoads, C. P. (1941). F. clin. Invest. 20, 749.

Bodansky, O., Lewis, J. M. \& Lillienfeld, M. C. C. (1943). I. clin. Invest. 22, 663.

Boller, R. \& Brunner, O. (1936). Klin. Wschr. 15, 1 106.

Boller, R., Brunner, O. \& Brodaty, E. (1937). Klin. Wschr. x6, 861 .

Campbell, D. A. \& Tonks, E. L. (I949). Brit. med. F. ii, 1499.

Catel, W. (1938a). Klin. Wschr. 17, 574.

Catel, W. (1938b). Mschr. Kinderheilk. 73, 316.

Chapman, D. G., Gluck, M., Common, R. H. \& Maw, W. A. (1949). Canad.F. Res. 27, sect. D, p. 37. Chevallier, A. \& Choron, Y. (1935). C.R. Soc. Biol., Paris, 120, 1223.

Clausen, S. W., Baum, W. S., McCoord, A. B., Kydeen, J. O. \& Breese, B. B. (1940). Science, 9r, 318. Clausen, S. W., Breese, B. B., Baum, W. S., McCoord, A. B. \& Rydeen, J. O. (I94I). Science, 93, 2 r. Dann, W. J. (1932). Biochem. F. 26, 1072.

Davies, A. W. \& Moore, T. (1948). Biochem. F. 42, Ixiii.

Eden, E. \& Moore, T. (1950). Biochem. F. 47, vi.

Ellison, J. B. \& Moore, T. (1937). Biochem. Э. 3I, I65.

Harris, A. D. \& Moore, T. (1947). Brit. med. $\mathcal{F} . \mathrm{i}, 553$.

Hume, E. M. (1951). Brit. F. Nutrit. 5, 104.

Hume, E. M. \& Krebs, H. A. (1949). Spec. Rep. Ser. med. Res. Coun., Lond., no. 264, p. 58.

Johnson, R. M. \& Baumann, C. A. (1947a). Arch. Biochem. 14, 361.

Johnson, R. M. \& Baumann, C. A. (1947b). Fed. Proc. 6, 265.

Kagan, B. M., Thomas, E. M., Jordan, D. A. \& Abt, A. F. (1950). F. clin. Invest. 29, 141.

Kimble, M. S. (1939). Y. Lab. clin. Med. 24, 1055.

Lawrie, N. R., McArdle, B. \& Moore, T. (1938). F. Soc. chem. Ind., Lond., 57, 189.

Lawrie, N. R., Moore, T. \& Rajagopal, K. R. (1941). Biochem. Y. 35, 825.

Le Gallic, P. (1947). C.R. Soc. Biol., Paris, 141, 1214.

Leitner, Z. A. (195I). Brit. F. Nutrit. 5, I30.

Lemley, J. M., Brown, R. A., Bird, O. D. \& Emmett, A. D. (1947). F. Nutrit. 33, 53.

Lindqvist, T. (1938). Studien über das Vitamin A beim Menschen. Uppsala: Appelbergs Boktryckenaktiebolag.

Medical Research Council (1949). Rep. med. Res. Coun., Lond., 1945-8, p. I14.

Meunier, P., Ferrando, R., Jouanneteau, J. \& Thomas, G. (1949). Bull. Soc. Chim. biol., Paris, 31, 1413.

Meunicr, P., Ferrando, R. \& Perrot-Thomas, G. (1950). Bull. Soc. Chim. biol., Paris, 32, 5o.

Moore, T. (1930). Biochem. $\mathcal{F} .24,692$.

Moore, T. (1937). Biochem. F. 31, 155 .

Moore, T. (1940). Biochem. F. 34, 1321 .

Moore, T. (1949). Spec. Rep. Ser. med. Res. Coun., Lond., no. 264, p. 62.

Moore, T. \& Leitner, Z. A. (1949). Spec. Rep. Ser. med. Res. Coun., Lond., no. 264, p. 65.

Moore, T., Martin, A. J. P. \& Rajagopal, K. R. (1939). Vitamin E. A Symposium, p. 4I. Cambridge: W. Heffer and Sons Ltd.

Moore, T. \& Sharman, I. M. (1950). Biochem. F. 47, xliii.

Moore, T. \& Wang, Y. L. (1945). Biochem. $\mathcal{F} .39,222$.

Murrill, W. A., Horton, P. B., Leiberman, E. \& Newburgh, L. H. (1941). F. clin. Invest. 20, 395.

Popper, H. \& Greenberg, R. (1941). Arch. Path 32, 11.

Shank, R. E., Coburn, A. F., Moore, L. V. \& Hoagland, C. L. (r944). F. clin. Invest. 23, 289. 